\title{
Frequency of Bacterial Isolates and Antimicrobial Sensitivity Pattern in Urogenital Fistulae: An Eight Years Audit
}

\author{
${ }^{1}$ Nasira Tasnim, ${ }^{2}$ Kausar T Bangash, ${ }^{3}$ Ayesha Hanif, ${ }^{4}$ Aathar Sayed
}

\begin{abstract}
Objective: To determine the frequency of urinary tract infection, distribution of microorganisms and their antimicrobial susceptibility pattern in urogenital fistula patients.

Place and duration of study: Eight years (April 2007-June 2015) at Mother And Child Health Centre, Shaheed Zulfiqar Ali Bhutto Medical University-Pakistan Institute of Medical Sciences (SZABMU-PIMS), Islamabad, a regional fistula center.

Study design: Descriptive study.

Patients and methods: All fistula patients entertained in $\mathrm{MCH}$ Center PIMS from April 2007 to June 2015 underwent detailed evaluation workup including baseline investigations. The specimen of urine was taken in sterile culture bottle and sent to a laboratory for biological evaluation. The data of all the patients was prospectively maintained from 2007-2015 and was analyzed using the statistical package for social sciences (SPSS) version 21. The main outcome measures included the frequency of urinary tract infection, distribution of bacterial isolates, and their susceptibility to antibiotics.
\end{abstract}

Results: During the study period 407 patients presented with urogenital fistula. The majority, $n=322,79.1 \%$, patients were of the reproductive age, i.e., below 40 years. The majority $n=$ $342,84 \%$ were Illiterate and $n=383,94 \%$ were housewives. The culture result was available in 259 (64\%). Of these bacterial isolates were found in 169 (65.2\%) patients, Candida species in $8(3 \%)$ patients while no organisms were found in remaining patients. Of 169 bacterial isolates, gram-negative isolates were found in $160(94 \%)$ patients followed by gram-positive isolates in $6(3.5 \%)$ and both, gram positive and gram negative isolates in $3(2 \%)$ patients. Klebseilla and E.coli was the most frequently occurring organisms (33\% and $29 \%$, respectively) followed by Pseudomonas. The highest sensitivity of bacterial isolates was found for Amikacin, imipenem, piperacillin, and tazobactam. The highest resistance was seen for amoxicillin + clavulanic acid, third generation antibiotics, quinolones, and nalidixic acid.

Conclusion: Urinary tract infection is prevalent among urogenital fistula patients. The resistance to most commonly prescribed

\footnotetext{
${ }^{1}$ Head MCH Unit 2, ${ }^{2}$ Associate Professor, ${ }^{3}$ Postgraduate Resident FCPS-II, ${ }^{4}$ Coordinator Fistula Project

${ }^{1}$ Department of Obstetrics and Gynecology, Pakistan Institute of Medical Sciences, Islamabad, Pakistan

${ }^{2-4}$ Department of Obstetrics and Gynecology MCH-2, SZABMUPakistan Institute of Medical Sciences, Islamabad, Pakistan

Corresponding Author: Nasira Tasnim, Head MCH Unit 2, Department of Obstetrics and Gynecology, Pakistan Institute of Medical Sciences, Islamabad, Pakistan, email: mchunit2@ gmail.com
}

low-cost oral antibiotics highlight the importance of prescribing antibiotics according to culture and sensitivity pattern and avoidance of injudicious use of antibiotics in fistula patients.

Keywords: Bacterial isolates, Urinary tract infection, Vesicovaginal fistula.

How to cite this article: Tasnim N, Bangash KT, Hanif A, Sayed A. Frequency of Bacterial Isolates and Antimicrobial Sensitivity Pattern in Urogenital Fistulae: An Eight Years Audit. J South Asian Feder Obst Gynae 2018;10(Suppl 1):343-346.

Source of support: Nil

Conflict of interest: None

Date of received: 17 March 2016

Date of acceptance: 11 April 2018

Date of publication: July 2019

\section{INTRODUCTION}

In developing countries, particularly Asia, where excess to emergency obstetric services is limited, the likelihood of complications is high. One of such complications is obstructed labor, the common sequelae of which is genital fistulae. It is estimated that more than 2 million young women live untreated with obstetric fistula. ${ }^{1}$ Not only that these patients suffer from social, mental and physical trauma due to continuous dribbling of urine, but also have frequent urinary tract infections. This predisposes to renal infections and also affects the wound healing if repair is done without treating the infection. ${ }^{2,3}$

As there is consistent communication between the bladder and vagina, the potential harbor of infection, these patients are likely to have a recurrent infection as well as difficulty in eradication. ${ }^{4,5}$ Since a prolonged postoperative catheterization is usually required to consume adequate tensile strength, there is an accumulation of bacteria on the catheter tip in case of untreated infection, leading to failure to respond to antibiotics, urethritis, bladder stones, and pyelonephritis. ${ }^{6}$

It is important to treat the infection well ahead of the surgical procedure and continue antibiotics for a long period due to prolonged catheterization. ${ }^{6,7}$

There is a scarcity of data regarding the frequency of urinary tract infection in the fistula patients, on the current distribution of microorganism and drugs sensi- 
tivity pattern. ${ }^{8}$ No local data are available in this regard. Therefore the study was conducted to determine the frequency of urinary tract infection in urogenital fistulae and distribution of microorganism and their antimicrobial susceptibility.

\section{PATIENTS AND METHODS}

All the fistula patients entertained in at Mother And Child Health Centre, Shaheed Zulfiqar Ali Bhutto Medical University-Pakistan Institute of Medical Sciences (SZABMU-PIMS), Islamabad, a regional fistula center for management of fistula patients working in collaboration with UNFPA, from April 2007 to June 2015 underwent detailed evaluation workup including baseline investigations. The catheter specimen of urine was taken in sterile culture bottle and sent to a laboratory for biological evaluation. Once received in the laboratory the specimen was cultured on cystine lactose electrolyte deficient (CLED) Agar at a temperature of $37^{\circ} \mathrm{C}$. A colony count of $15-20$ was considered to be significant for antimicrobial sensitivity assessment.

The data of all the patients was prospectively maintained from 2007 to 2015 and was analyzed using SPSS version 21 .

The main outcome measures included the frequency of urinary tract infection, distribution of bacterial isolates, and their susceptibility to antibiotics.

\section{RESULTS}

During the study period (April 2007-June 2015) 407 patients presented with genital fistula. The majority ( $\mathrm{n}=322,79.1 \%$ ) patients were of the reproductive age, i.e., below 40 years of age. Majority $(n=342,84 \%)$ were Illiterate and majority ( $n=383,94 \%)$ were housewives. The culture result was available in 259 (64\%). Of these bacterial isolates were found in 169 (65.2\%) patients, Candida species in $8(3 \%)$ patients while no organisms were found in remaining patients. Of 169 bacterial isolates, gram-negative isolates were found in 160 (94\%)

Table 1: Distribution of bacterial isolates among urogenital fistulae

\begin{tabular}{ll}
\hline Bacterial isolate & $\begin{array}{l}\text { Number (\%) of bacterial } \\
\text { isolates }\end{array}$ \\
\hline Escherichia coli & $53(31)$ \\
Pseudomonas species & $26(15)$ \\
Escherichia coli + Proteus species & $2(1.1)$ \\
Klebsiella species & $59(35)$ \\
Staphylococcus auerus & $6(3.5)$ \\
Proteus species & $17(10)$ \\
Klebsiella species + & $3(1.7)$ \\
Staphylococcus auerus & \\
Enterobacter & $3(1.7)$ \\
\hline
\end{tabular}

patients followed by gram-positive isolates in $6(3.5 \%)$ and both, gram positive and gram negative isolates in 3 (2\%) patients Klebseilla and E.coli was the most frequently occurring organisms (33\% and 29\%, respectively) followed by Pseudomonas (Table 1).

Referring to Table 2, the highest sensitivity among bacterial isolates was found for amikacin, imipenem, piperacillin, and tazobactam. The same trend for the sensitivity pattern was found among individual isolates as shown in Table 3.

Referring to Table 4, the highest resistance among bacterial isolates was seen for amoxicillin + clavulanic acid, third generation antibiotics, quinolones, and nalidixic acid. A similar trend for antimicrobial resistance pattern was seen among individual bacterial isolates as shown in Table 5.

\section{DISCUSSION}

The results of the study clearly show that the urinary tract infection is highly prevalent $(68.3 \%)$ among women with urogenital fistulae. Varying incidence has been reported in the literature; $52.8 \%$ by Wondomeneh et al., ${ }^{9} 76 \%$ by Erin et al., ${ }^{10} 8 \%$ by Adeoye et al. ${ }^{11}$ and $9.25 \%$ Kabir et al. ${ }^{12}$ The most likely reason for such a high prevalence of bacterial isolates among these patients is direct communication between vagina, a potential harbor for bacteria and urinary tract. The other possibility is that most of these fistulae are obstetric in nature, resulting from prolonged labor. Repeated catherization has also been shown to play a role as has been shown by Wondomeneh et al. ${ }^{9}$

The situation is further alarmed by the fact that the majority of these patients were asymptomatic. The reports from the other parts of the world where the urogenital fistulae are highly prevalent also indicate that majority of the patients with positive isolates have asymptomatic bacteriuria. ${ }^{11,13-16}$ Asymptomatic bacteriuria has usually not been found to be associated with significant adverse outcome. However, patients undergoing fistulae repair surgery need to be treated before undergoing such surgery, as the success of the procedure may be adversely

Table 2: Distribution of antibiotics sensitivity pattern among bacterial isolates

\begin{tabular}{ll}
\hline Antimicrobial & $\begin{array}{l}\text { Number }(\%) \text { of } \\
\text { bacterial isolates }\end{array}$ \\
\hline Amikacin & $81(20.2)$ \\
Amoxacillin + cluvanic acid & $24(6)$ \\
Cefoparazone + sulbactum & $33(8.2)$ \\
Ceftazidine & $30(7.5)$ \\
Ceftriaxone & $20(5)$ \\
Ciprofloxacin & $30(7.5)$ \\
Imipenim & $76(19)$ \\
Nalidixic acid & $12(3)$ \\
Nitrofurantoin & $23(5.7)$ \\
Piperacillin + tazobactum & $71(17.7)$ \\
\hline
\end{tabular}


Frequency of Bacterial Isolates and Antimicrobial Sensitivity Pattern in Urogenital Fistulae: An Eight Years Audit

Table 3: Distribution of antimicrobial sensitivity pattern against individual bacterial isolates

\begin{tabular}{|c|c|c|c|c|c|c|c|c|c|c|}
\hline \multirow[b]{2}{*}{ Bacterial isolates } & \multicolumn{10}{|c|}{ Antimicrobial agents } \\
\hline & $A M I$ & $\begin{array}{l}\text { AMOX + } \\
\text { CLUV }\end{array}$ & $\begin{array}{l}\text { CEF+ } \\
\text { SUL }\end{array}$ & CEFT & $\mathrm{CRO}$ & CIPRO & IMI & $N A X$ & NITRO & $\begin{array}{l}\text { PIP + } \\
\text { TAZO }\end{array}$ \\
\hline Escherichia coli & $\begin{array}{l}32 \\
(60.4)\end{array}$ & $\begin{array}{l}2 \\
(3.8)\end{array}$ & $\begin{array}{l}16 \\
(30.2)\end{array}$ & $\begin{array}{l}11 \\
(20.8)\end{array}$ & $\begin{array}{l}3 \\
(5.7)\end{array}$ & $\begin{array}{l}14 \\
(26.4)\end{array}$ & $\begin{array}{l}28 \\
(52.8)\end{array}$ & $\begin{array}{l}7 \\
(13.2)\end{array}$ & $3(5.7)$ & $\begin{array}{l}27 \\
(51)\end{array}$ \\
\hline Pseudomonas species & $\begin{array}{l}15 \\
(57.7)\end{array}$ & $\begin{array}{l}6 \\
(23.1)\end{array}$ & $\begin{array}{l}1 \\
(3.8)\end{array}$ & $\begin{array}{l}10 \\
(38.5)\end{array}$ & $\begin{array}{l}9 \\
(34.6)\end{array}$ & $\begin{array}{l}4 \\
(15.4)\end{array}$ & $\begin{array}{l}5 \\
(19.2)\end{array}$ & $\begin{array}{l}0 \\
(0)\end{array}$ & $\begin{array}{l}8 \\
(30.8)\end{array}$ & $\begin{array}{l}13 \\
(50)\end{array}$ \\
\hline Escherichia coli + Proteus species & $\begin{array}{l}2 \\
(100)\end{array}$ & $\begin{array}{l}0 \\
(0)\end{array}$ & $\begin{array}{l}0 \\
(0)\end{array}$ & $\begin{array}{l}0 \\
(0)\end{array}$ & $\begin{array}{l}0 \\
(0)\end{array}$ & $\begin{array}{l}2 \\
(100)\end{array}$ & $\begin{array}{l}1 \\
(50)\end{array}$ & $\begin{array}{l}0 \\
(0)\end{array}$ & $\begin{array}{l}1 \\
(50)\end{array}$ & $\begin{array}{l}0 \\
(0)\end{array}$ \\
\hline Klebsiella species & $\begin{array}{l}26 \\
(44.1)\end{array}$ & $\begin{array}{l}7 \\
(11.9)\end{array}$ & $\begin{array}{l}10 \\
(16.9)\end{array}$ & $\begin{array}{l}6 \\
(8.5)\end{array}$ & $\begin{array}{l}3 \\
(5.1)\end{array}$ & $\begin{array}{l}24 \\
(6.8)\end{array}$ & $\begin{array}{l}24 \\
(40.7)\end{array}$ & $\begin{array}{l}4 \\
(6.8)\end{array}$ & $\begin{array}{l}7 \\
(11.9)\end{array}$ & $\begin{array}{l}18 \\
(30.5)\end{array}$ \\
\hline Staphylococcus auerus & $\begin{array}{l}0 \\
(0)\end{array}$ & $\begin{array}{l}0 \\
(0)\end{array}$ & $\begin{array}{l}0 \\
(0)\end{array}$ & $\begin{array}{l}1 \\
(20)\end{array}$ & $\begin{array}{l}1 \\
(20)\end{array}$ & $\begin{array}{l}0 \\
(0)\end{array}$ & $\begin{array}{l}0 \\
(0)\end{array}$ & $\begin{array}{l}0 \\
(0)\end{array}$ & $\begin{array}{l}0 \\
(0)\end{array}$ & $\begin{array}{l}0 \\
(0)\end{array}$ \\
\hline Proteus species & $\begin{array}{l}3 \\
(17.6)\end{array}$ & $\begin{array}{l}5 \\
(29.4)\end{array}$ & $\begin{array}{l}3 \\
(17.6)\end{array}$ & $\begin{array}{l}2 \\
(11.8)\end{array}$ & $\begin{array}{l}2 \\
(11.8)\end{array}$ & $\begin{array}{l}4 \\
(23.5)\end{array}$ & $\begin{array}{l}9 \\
(52.9)\end{array}$ & $\begin{array}{l}1 \\
(5.9)\end{array}$ & $\begin{array}{l}4 \\
(23.5)\end{array}$ & $\begin{array}{l}8 \\
(47.1)\end{array}$ \\
\hline Klebsiella species + Staphylococcus auerus & $\begin{array}{l}0 \\
(0)\end{array}$ & $\begin{array}{l}0 \\
(0)\end{array}$ & $\begin{array}{l}3 \\
(100)\end{array}$ & $\begin{array}{l}0 \\
(0)\end{array}$ & $\begin{array}{l}0 \\
(0)\end{array}$ & $\begin{array}{l}3 \\
(100)\end{array}$ & $\begin{array}{l}0 \\
(0)\end{array}$ & $\begin{array}{l}0 \\
(0)\end{array}$ & $\begin{array}{l}0 \\
(0)\end{array}$ & $\begin{array}{l}3 \\
(100)\end{array}$ \\
\hline Enterobacter & $\begin{array}{l}3 \\
(100) \\
\end{array}$ & $\begin{array}{l}0 \\
(0) \\
\end{array}$ & $\begin{array}{l}0 \\
(0) \\
\end{array}$ & $\begin{array}{l}0 \\
(0) \\
\end{array}$ & $\begin{array}{l}0 \\
(0) \\
\end{array}$ & $\begin{array}{l}0 \\
(0) \\
\end{array}$ & $\begin{array}{l}1 \\
(33)\end{array}$ & $\begin{array}{l}0 \\
(0) \\
\end{array}$ & $\begin{array}{l}0 \\
(0)\end{array}$ & $\begin{array}{l}2 \\
(66.7)\end{array}$ \\
\hline
\end{tabular}

AMI, amikacain; AMOX+CLUV, amoxacillin + cluvanic acid; CEF+SUL, cefoprazone+sulbactum; CEF, ceftazidine; CRO, ceftriaxone; CIPRO, ciprfloxacin; IMI, imipenum; NAX, nalidixic acid; NITRO, nitrofurantoin; PIP+TAZO, piperacillin + tazobactum

Table 4: Degree of susceptibility of bacterial isolates to various antibiotics

\begin{tabular}{ll}
\hline Antimicrobial & $\begin{array}{l}\text { Number }(\%) \text { of } \\
\text { Bacterial Isolates }\end{array}$ \\
\hline Amikacin & $32(7.9)$ \\
Amoxacillin + cluvanic acid & $65(16.2)$ \\
Cefoparazone + sulbactum & $17(4.2)$ \\
Ceftazidine & $64(15.9)$ \\
Ceftriaxone & $67(16.7)$ \\
Ciprofloxacin & $59(14.7)$ \\
Imipenim & $0(0)$ \\
Nalidixic acid & $50(12.4)$ \\
Nitrofurantoin & $17(4.2)$ \\
Piperacillin + tazobactum & $30(7.4)$ \\
\hline
\end{tabular}

affected by the bacterial infection as has been indicated by other authors as well. ${ }^{17-19}$ Conversion to symptomatic bacteria is an additional concern in this regard. ${ }^{14,17,20}$

The gram-negative organisms were the predominant bacterial isolates in our study, the most prevalent being Klebseilla, E. coli, and Pseudomonas. The other authors have also reported similar findings, E.coli, Proteus and Klebsiella being the most prevalent organisms. ${ }^{11,14,15,21,22}$ The high prevalence of $E$. coli is considered to be due to its virulence factor for colonization and invasion of the urinary epithelium. However, some rare isolates like Citrobacter may be the most prevalent uropathogenic as shown by Wondomeneh et al. ${ }^{9}$

Table 5: Distributtion of antimicrobial resistant pattern against individual bacterial isolates

\begin{tabular}{|c|c|c|c|c|c|c|c|c|c|c|}
\hline \multirow[b]{2}{*}{ Bacterial isolates } & \multicolumn{10}{|c|}{ Antimicrobial agents } \\
\hline & $A M I$ & $\begin{array}{l}\text { AMOX } \\
+ \\
\text { CLUV }\end{array}$ & $\begin{array}{l}\text { CEF+ } \\
\text { SUL }\end{array}$ & CEFT & CRO & CIPRO & $I M I$ & NAX & NITRO & $\begin{array}{l}\text { PIP + } \\
\text { TAZO }\end{array}$ \\
\hline Escherichia coli & $\begin{array}{l}6 \\
(11.5)\end{array}$ & $\begin{array}{l}32 \\
(61.5)\end{array}$ & $\begin{array}{l}1 \\
(1.9)\end{array}$ & $\begin{array}{l}19 \\
(36.5)\end{array}$ & $\begin{array}{l}17 \\
(32.7)\end{array}$ & $\begin{array}{l}8 \\
(15.4)\end{array}$ & $\begin{array}{l}0 \\
(0)\end{array}$ & $\begin{array}{l}10 \\
(19.2)\end{array}$ & $\begin{array}{l}3 \\
(5.8)\end{array}$ & $\begin{array}{l}5 \\
(9.6)\end{array}$ \\
\hline Pseudomonas species & $\begin{array}{l}6 \\
(23.1)\end{array}$ & $\begin{array}{l}0 \\
(0)\end{array}$ & $\begin{array}{l}6 \\
(23.1)\end{array}$ & $\begin{array}{l}8 \\
(30.8)\end{array}$ & $\begin{array}{l}6 \\
(23.1)\end{array}$ & $\begin{array}{l}10 \\
(38.5)\end{array}$ & $\begin{array}{l}0 \\
(0)\end{array}$ & $\begin{array}{l}5 \\
(19.2)\end{array}$ & $\begin{array}{l}2 \\
(7.7)\end{array}$ & $\begin{array}{l}4 \\
(15.4)\end{array}$ \\
\hline Escherichia coli + Proteus species & $\begin{array}{l}0 \\
(0)\end{array}$ & $\begin{array}{l}1 \\
(50)\end{array}$ & $\begin{array}{l}0 \\
(0)\end{array}$ & $\begin{array}{l}0 \\
(0)\end{array}$ & $\begin{array}{l}1 \\
(50)\end{array}$ & $\begin{array}{l}0 \\
(0)\end{array}$ & $\begin{array}{l}0 \\
(0)\end{array}$ & $\begin{array}{l}0 \\
(0)\end{array}$ & $\begin{array}{l}0 \\
(0)\end{array}$ & $\begin{array}{l}0 \\
(0)\end{array}$ \\
\hline Klebsiella species & $\begin{array}{l}12 \\
(20.3)\end{array}$ & $\begin{array}{l}22 \\
(37.3)\end{array}$ & $\begin{array}{l}6 \\
(10.2)\end{array}$ & $\begin{array}{l}24 \\
(40.7)\end{array}$ & $\begin{array}{l}29 \\
(49.2)\end{array}$ & $\begin{array}{l}28 \\
(47.5)\end{array}$ & $\begin{array}{l}0 \\
(0)\end{array}$ & $\begin{array}{l}19 \\
(32.2)\end{array}$ & $\begin{array}{l}4 \\
(6.8)\end{array}$ & $\begin{array}{l}17 \\
(28.8)\end{array}$ \\
\hline Staphylococcus auerus & $\begin{array}{l}0 \\
(0)\end{array}$ & $\begin{array}{l}0 \\
(0)\end{array}$ & $\begin{array}{l}0 \\
(0)\end{array}$ & $\begin{array}{l}0 \\
(0)\end{array}$ & $\begin{array}{l}0 \\
(0)\end{array}$ & $\begin{array}{l}5 \\
(83.3)\end{array}$ & $\begin{array}{l}0 \\
(0)\end{array}$ & $0(0)$ & $\begin{array}{l}4 \\
(66.7)\end{array}$ & $\begin{array}{l}0 \\
(0)\end{array}$ \\
\hline Proteus species & $\begin{array}{l}4 \\
(23.5)\end{array}$ & $\begin{array}{l}4 \\
(23.5)\end{array}$ & $\begin{array}{l}3 \\
(17.6)\end{array}$ & $\begin{array}{l}2 \\
(11.8)\end{array}$ & $\begin{array}{l}4 \\
(23.5)\end{array}$ & $\begin{array}{l}3 \\
(17.6)\end{array}$ & $\begin{array}{l}0 \\
(0)\end{array}$ & $\begin{array}{l}3 \\
(100)\end{array}$ & $\begin{array}{l}0 \\
(100)\end{array}$ & $\begin{array}{l}3 \\
(100)\end{array}$ \\
\hline Klebsiella species + Staphylococcus auerus & $\begin{array}{l}0 \\
(0)\end{array}$ & $\begin{array}{l}3 \\
(100)\end{array}$ & $\begin{array}{l}0 \\
(0)\end{array}$ & $\begin{array}{l}3 \\
(100)\end{array}$ & $\begin{array}{l}3 \\
(100)\end{array}$ & $\begin{array}{l}0 \\
(0)\end{array}$ & $\begin{array}{l}0 \\
(0)\end{array}$ & $\begin{array}{l}3 \\
(100)\end{array}$ & $\begin{array}{l}0 \\
(0)\end{array}$ & $\begin{array}{l}3 \\
(100)\end{array}$ \\
\hline Enterobacter & $\begin{array}{l}0 \\
(0) \\
\end{array}$ & $\begin{array}{l}3 \\
(100) \\
\end{array}$ & $\begin{array}{l}1 \\
(33.3) \\
\end{array}$ & $\begin{array}{l}0 \\
(0) \\
\end{array}$ & $\begin{array}{l}3 \\
(100) \\
\end{array}$ & $\begin{array}{l}1 \\
(33.3)\end{array}$ & $\begin{array}{l}0 \\
(0)\end{array}$ & $\begin{array}{l}2 \\
(66.7) \\
\end{array}$ & $\begin{array}{l}0 \\
(0)\end{array}$ & $\begin{array}{l}1 \\
(33.3) \\
\end{array}$ \\
\hline
\end{tabular}

AMI, amikacain; AMOX + CLUV, amoxacillin + cluvanicacid; CEF + SUL, cefoprazone + sulbactum; CEF, ceftazidine; CRO, ceftriaxone; CIPRO, ciprfloxacin; IMI, imipenum; NAX, nalidixic acid; NITRO, nitrofurantoin; PIP + TAZO, piperacillin + tazobactum 
Majority of the isolates were sensitive to amikacin, imipenem, piperacillin, and tazobactam. The major concern in this regard is that all these drugs are available only in injectable forms and are expensive, especially the latter two. The issue is further complicated by the fact that the majority of the isolates are resistant to commonly prescribed oral preparations including amoxilin + cluvanic acid, ceftazidime, and ciprofloxacin. The probable reason for such high antibiotic resistance to a commonly prescribed antibiotic is due to the previous exposure to these antibiotics as the majority of the patients belonged to rural settings, where antibiotics are used randomly without culture and sensitivity pattern. Suboptimum dosage and intermediate sensitivity may be responsible for the development of antibiotic resistance. The similar findings were also reported in other studies. ${ }^{23,24}$

The study is limited by the fact that it was a retrospective analysis thus many predisposing factors such as the previous history of catheterization and use of antibiotic could not be ascertained as has been shown by other authors. ${ }^{9}$

\section{CONCLUSION}

Urinary tract infection is prevalent among urogenital fistula patients. The resistance to most commonly prescribed low-cost oral antibiotics highlight the importance of prescribing antibiotics according to culture and sensitivity pattern and avoidance of injudicious use of antibiotics in fistula patients.

\section{ACKNOWLEDGMENTS}

Authors are thankful to UNFPA for funding the fistula project and Mr Muhammad Shafique Arif, Director Surveys and Field Research Oxford Policy Management Islamabad, for analyzing the data.

\section{REFERENCES}

1. Creanga A, Ahmed S, et al. Prevention and treatment of obstetric fistula: identifying research need and public health priorities. Int J Gynaecol Obstet 2007;99:S154.

2. Columbia University sponsored second meeting of the working group for the prevention and treatment of obstetric fistula. Addis Ababa: UNFPA, FIGO; 2002

3. Miller S, Lester F, et al. Obstetric fistula; a preventable tragedy. J Midwifery Women Health 2005;50:286-294.

4. Emembolu J. The obstetric fistula: factors associated with improved pregnancy outcome after a successful repair. Int J Gynaecol Obstet 1992;39(3):205-212.

5. Ebie M Kandakai O, Ayanbadejo J, et al. Urinary tract infections. Nigeria J Microbiol 2001;15(1):31-37.
6. Nardos R, Browning A, et al. Duration of bladder catheterization after surgery for obstetric fistulae. Int Gynaecol Obstet 2008;103(1):30-32

7. Igawa $Y$, Wyndaele J-J, et al. Catheterization possible complications and their prevention and treatment. Int J Urol 2008;15(6): 481-485.

8. Lassey AT. Simple fistula: diagnosis and management in lowresource setting a descriptive report. Int J Gynecol Obstetr 2007:S47-S50.

9. Wondomeneh $\mathrm{Y}$, Muluye D, et al. Urinary tract infection among obstetric fistula patients at Gondar University Hospital, Northwest Ethiopia. BMC Women's Health 2014;14(1):12.

10. Erin MF, Sarah JT, et al. Retrospective review of predisposing factors and surgical outcomes in obstetric fistula patients at a single teaching hospital in Western Kenya. J Obstet Gynecol 2011;33(1):30-35

11. Adeoye SI, Oladeinde $\mathrm{O}$, et al. An assessment of asymptomatic bacteriuia among women with vesico-vaginal fistula in southeastern Nigeria. Nepal J Epidemiol 2011;1(2):64-69.

12. Kabir M, Iliyasu Z, et al. Medico-social problems of patients with vesicovaginal fistula in murtala mohammed specialist hospital , kano. Ann Afr Med 2003,2(2):54-57

13. Wall LL, karshima JA, et al. The obstetric Vesicovaginal fistula: characteristic of 899 patients from Jos, NigeriAm J Obstet Gynecol 2004;190(4):1011-1019

14. Yabaya A, Auta B. Microorganisms associated with the urinogenital system of vesico vaginal fistula (VVF) patients in north western Nigeria. Sci World J 2006;1(1):37.

15. Ojanuga OD, Ekwempu CC. An investigation of sociomedical risk factors associated with vaginal fistula in northern Nigeria. Women health 1999;28(3):103-116.

16. Ghatal DP. A study of urinary fistulae in Sokoto, Nigeria. J Indian Med Assoc 1992:90(11):285-287.

17. Nicolle LE. Asymptomatic bacteriuria-Important or Not? N Engl Med 2000; 343:1037-1039.

18. Nicolle LE. Asymptomatic Bacteriuria: review and discussion of the IDSA guidelines. Int J Antimicrob Agents 2006;28(Suppl 1): S42-48.

19. Paige NM, Vazirani SS, et al. The top 10 infectious disease pitfalls that hospitalists can avoid . J Hosp Med 2010;5(1):42-45.

20. Lin K, Farjardo K. US preventive services task force. Screening for asymptmatic bacteriuria in adults: evidence for the U>S. Preventive Services Task Force reaffirmation recommendation statement. Ann Intern Med 2008 1;149(1):W20-24.

21. Ferede G, Yismaw G, et al. The prevalence and antimircrobial susceptibility pattern of bacterial uropathogens, Isolated from pregnant women. Eur J Exp Biol 2012;2(5):147-150.

22. Assefa A, Asrat D, et al. Bacterial profile and drug susceptibility pattern of urinary tract infection in pregnant women at Tikur Anbessa specialized hospital Addis Ababa, Ethiopia. Ethiopia Med J 2008;46:227-235.

23. Saderi $\mathrm{H}$, Owlia P. Detection of multidrug resistant (MDR) and extremely drug resistant (XDR) P. Aeruginosa isolated from patients in Tehran, Iran. J Pathol Iran 2015;10(4):265-271.

24. Asad U, Mohd S. Multiple drug resistance pattern in urinary tract infection patients in Aligrah. Biomed Res 2006;17:179-181. 